Arab Univ. J. Agric. Sci., Ain Shams Univ., Cairo, 13(2), 351 - 365, 2005

\title{
UTILIZATION OF CORN GERM AND SUNFLOWER SEEDS AS A NEW SOURCES OF LECITHINS AND THEIR MODIFIED FORMS IN MANUFACTURE OF CARAMEL [22]
}

\author{
Kishk $^{1}$, Y.F.M. and Salwa, M. Abo-El-Fetoh ${ }^{1}$
}

\begin{abstract}
Fractionation and acylation by ethyl alcohol and acetic anhydride were carried out to produce a modified corn germ and sunflower lecithins from their crude lecithins. Emulsification activity and emulsion stability indices (EAI \& ESI) were determined at different $\mathrm{pH}$ values $(2,4,6,8$ and 10) for commercial and studied lecithins. EAI was significantly improved in modified lecithins in comparison to crude lecithins with increasing rate of 52.9 and $58.6 \%$ for corn germ and sunflower ethanol soluble fraction lecithins and 15.6 and $20.5 \%$ for acylated corn germ and sunflower lecithins, respectively. The changes in ESI after times of 20, 40 and $60 \mathrm{~min}$. showed a higher stability of emulsions prepared using modified lecithins which were closed to that prepared using commercial soy lecithin. Caramel was prepared using commercial soy, corn germ, sunflower lecithins and their modified forms. Hardness of tested samples was determined in the start of storage time while, acid value, peroxide value, fatty acid pattern and sensory attributes were determined during storage period at room temperature for six months. Data revealed insignificant difference in caramels hardness. Samples contained crude sunflower; acylated corn germ and sunflower lecithins were more sensitive to oxidation while, those prepared using commercial soy, crude corn germ, ethanol soluble fraction of corn germ and sunflower lecithins showed higher oxidative stability with significant differences $(\mathrm{P}<0.05)$. Concerning sensory evaluation, both ethanol soluble fractions and acylated lecithins produced high quality caramels not differed $(\mathrm{P}>0.05)$ to control one that contained commercial soy lecithin. The quality and quantity of lecithin that used in prepared of caramel samples played a major role in their characteristics. The modified corn germ and sunflower lecithin forms were preferred than the raw lecithins owing to their higher emulsifying activity and lesser quantity used. The ethanol soluble lecithins fraction, especially of corn germ can be competitive to the commercial soy lecithin in all emulsified food products.
\end{abstract}

Key words: Caramel, Modified lecithin, Corn germ, Sunflower, Emulsifying activity, Emulsion stability.

1- Food Sci. Dept., Fac. Agric., Ain Shams Univ., Shoubra El-Kheima, Cairo, Egypt. 


\section{INTRODUCTION}

Under European legislation lecithins are labeled as "lecithin" or "E322" in the food additive group of substances with antioxidants properties. However, their main use is as emulsifiers (Van Nieuwenhuyzen, 1999). Lecithin can be produced from any crude vegetable oil, but because of the huge quantities of soybeans grown and processed and owing to the relatively high percentage of phosphatides in soybean oil practically all over world, soybean oil is the principal commercial source of natural and modified lecithins (Hollo et al 1993). In Egypt corn germ and sunflower seeds are the major source of oils. Thus, corn germ and sunflower oils must be considered as potential sources of lecithins. Distribution of the main phospholipid components of corn germ and sunflower lecithins appears to be rather similar to that of soybean lecithin. Comparison of published data shows no significant difference between soybean and sunflower lecithins, but it points to poorer surface activity of the latter. Concerning of corn germ lecithin, it has higher phosphatidylcholine content than in soybean lecithin (Weber, 1981; Hollo et al 1993).

Lecithin commonly refers to a mixture of phospholipids dissolved in oil. Crude lecithin contains $\approx 60 \%$ phospholipids and $30 \%$ oil, dry basis (Temelli and Dunford, 1995). Deoiling of crude lecithin is considered necessary in making high purity lecithin products. Acetone is currently used in industry for the separation of neutral oil and phospholipids, based on the fact that neutral oil is soluble in acetone but phospholipids are not (Wu and Wang, 2003). The crude lecithin can be fractionated into ethanol solu- ble and insoluble fractions. Phosphatidylcholine (PC) dissolves faster than phosphatidylethanolamine (PE) and other acid-reacting phospholipids in ethanol, so that ethanol-soluble fractions contain a much higher PC/PE ratio. Acylation of the phosphatidylethanolamine enhances hydrophilicity and heat stability (Van Nieuwenhuyzen, 1999). The phospholipid molecule contains both a lipophilic fatty acyl group and a hydrophilic head group, and this amphiphilic structure make it a good surface-tension-reducing agent and thus a good emulsifier (Krog, 1997).

Emulsion stability refers to the ability of an emulsion to resist changes in its physical properties over time: the more stable the emulsion, the more slowly the phases separate. Phosphatidylcholine and phosphatidylethanolamine enriched fractions were used as emulsifiers for creating both $\mathrm{o} / \mathrm{w}$ and w/o emulsions for the emulsion stability test (Wu and Wang, 2003).

The purpose of using emulsifiers in caramel, toffee and fudge is to stabilize the fat distribution within the sugar mass, because with high fat content in these products, the manipulation of plastic masses can squeeze out of fat leading to the risk of surface oxidation and unsightly appearance. For these reasons and also to maintain a good fat distribution, which lubricates the cutting knives, emulsifiers are more frequently used in cut and wrap processes (Stansell, 1995). Caramel is basically oil in water emulsion, with the water phase comprising of highly concentrated sugar syrup. The oil phase was traditionally butter, though vegetable fats are commonly used now (Smith, 1998).

The fat and lecithin helps in flavor and texture by reducing stickiness and 
softening the bite. The emulsion activity of the lecithin used has a significant effect on the finished caramel texture and product standup (Heim, 2003).

In this study, crude corn germ and sunflower lecithins were fractionated and acylated to produce phosphatidylcholine enriched fractions and to enhance hydrophilicity of phosphatidylethanolamine. The modified lecithins were evaluated for their emulsification activity and stability indices. The crude corn germ, sunflower lecithins and their modified forms were used in manufacturing of caramel in comparison to commercial soybean lecithin, which, import from other countries.

\section{MATERIAL AND METHODS}

\section{Materials}

Corn and sunflower oil crude wet gums used in preparation of lecithins were obtained from Arma Food Industry company $10^{\text {th }}$ of Ramadan city, Egypt and Misr Gulf Oil Processing Company (MIGOP) Suez city, Egypt. Commercial soy lecithin was obtained from the Egyptian Company for Food (Biscomisr), Ammeria, Cairo, Egypt. However, sweetened condensed whole milk (SCWM), sucrose, palm oil and salt $(\mathrm{NaCl})$ were purchased from the local market, Cairo, Egypt.

\section{Methods}

\section{Extraction of lecithin}

The extraction of lecithin was carried out according to Sosada et al (1994). Crude wet gum was centrifuged at $4000 \mathrm{~g}$ for $15 \mathrm{~min}$. The precipitate was collected as reduced oil wet gum, diluted with an appropriate volume of acetone and blend- ed in warring blendor (Model 32 BL 80) at high speed for $5 \mathrm{~min}$. The mixture was centrifuged at $2000 \mathrm{~g}$ for $10 \mathrm{~min}$. The extraction with acetone was repeated for three times, and the precipitate was dried under vacuum at $25{ }^{\circ} \mathrm{C}$ for $12 \mathrm{hrs}$. The produced lecithins identified as crude lecithins.

\section{Modification of lecithins}

Fractionation: Ethyl alcohol soluble fraction of corn germ and sunflower lecithins were prepared by stirring crude lecithins with ethyl alcohol $(1: 5 \mathrm{w} / \mathrm{v})$ at 45 ${ }^{\circ} \mathrm{C}$ for $30 \mathrm{~min}$ and; then standing for 60 min. to separate the two layers. The upper layer was transferred to rotary evaporator to evaporate alcohol under vacuum.

Acylation: Corn germ and sunflower crude wet gums were acylated with 1.5 mol equivalent of acetic anhydride based on phosphatidylethanolamine (PE) content. Potassium hydroxide was added to the gum to neutralize acetic acid generated during the reaction. Acylation was carried out at $60^{\circ} \mathrm{C}$ for $1 \mathrm{hr}$. Thereafter, the acylated lecithin was separated as mentioned above in lecithin extraction, then dried under vacuum at $40{ }^{\circ} \mathrm{C}$ for 12 hr.

The procedures recommended by Hollo et al (1993) were applied to prepared the modified lecithins.

\section{Emulsifying activity and emulsion sta- bility indices}

Emulsifying activity index (EAI) $\left(\mathrm{m}^{2}\right.$ $\mathrm{g}^{-1}$ ) was determined at different $\mathrm{pH}$ values $(2,4,6,8$ and 10) according to Pearce and Kinsella (1978). Ten $\mathrm{ml}$ of corn oil and $30 \mathrm{ml}$ of aqueous lecithin solution $(5 \mathrm{mg} / \mathrm{ml}$ water $)$ were homoge- 
nized by waring blendor for $60 \mathrm{sec}$. A 0.1 $\mathrm{ml}$ of sample was immediately taken from the bottom of the container and diluted to $50 \mathrm{ml}$ with $0.1 \%$ sodium dodecyl sulfate. The absorbance of the diluted emulsion (A) was measured at $500_{\mathrm{nm}}$. The initial $\mathrm{A}_{500 \mathrm{~nm}}$ measurement was taken to be the emulsifying activity index (EAI), while emulsion stability index (ESI) was

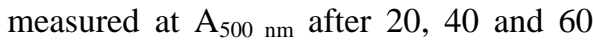
min. EAI or ESI were calculated as follows:

$$
E A I \text { or ESI }=\frac{2 \times 2.303 \times A_{500 \mathrm{~nm}}}{\begin{array}{c}
25 \times \text { length of cuvette } x \\
\text { Lecithin concentration }
\end{array}}
$$

Caramel preparation

Caramel samples in $1 \mathrm{Kg}$ lots were prepared according to Tonucci and Von Elbe (1988) by premixing the fat with commercial soy lecithin emulsifier and melted together at $80^{\circ} \mathrm{C}$, in a stainless steel mixing bowl. The temperature was allowed to drop to just above the melting range of the fat $\left(35\right.$ to $\left.40^{\circ} \mathrm{C}\right)$ at which time SCWM and corn syrup were added. The mixture was blended for 2 min. until smooth. Sugar and salt were added slowly and mixing was continued for $15 \mathrm{~min}$. The caramel mix was cooked until the final temperature reached of $118{ }^{\circ} \mathrm{C}$, and then cooled by leaving it on a steel table. The cooled samples were then cut into cylindrical pieces $(19 \mathrm{~mm}$ in diameter and $19 \mathrm{~mm}$ in width), wrapped in moisture-proof paper and stored at room temperature for later use. The caramel formulation was as follows:

$\begin{array}{cccc}\text { Ingredient } & \boldsymbol{\%} & \text { Ingredient } & \boldsymbol{\%} \\ \text { Corn syrup } & 39.9 & \text { Fat } & 9.9\end{array}$

$\begin{array}{llll}\text { SCWM } & 34.9 & \begin{array}{l}\text { Salt }(\mathrm{NaCl}) \\ \text { Commercial }\end{array} & 0.3 \\ \text { Sucrose } & 14.9 & \begin{array}{l}\text { soy lecithin } \\ \text { sol }\end{array} & \end{array}$

The commercial soy lecithin was replaced by an equivalent amounts of tested lecithins based on their emulsifying activity, to be equal to that of soy lecithins. The calculated amounts of lecithins added to $1 \mathrm{Kg}$ caramel corresponded to $1.0 \mathrm{~g}$ soy lecithin were $1.7,2.0 ; 1.0,1.1 ; 1.3$ and $1.4 \mathrm{~g}$ for crude, ethanol soluble fraction and acylated corn germ and sunflower lecithins.

\section{Caramel hardness}

Caramels were measured for their hardness according to the method described by Tonucci and Von Elbe (1988) using Instron Universal Testing Machine. Cylindrical caramel pieces were held at $22{ }^{\circ} \mathrm{C}$ in an incubator for $24 \mathrm{hr}$. A load cell used had a maximum capacity of $1000 \mathrm{~N}$. The rate of compression was 2 $\mathrm{mm} /$ minute and the chart speed was 50 $\mathrm{mm} / \mathrm{min}$.

\section{Fat analyses}

Lipids were extracted from caramel samples according to the method described by Pearson (1976). Acid, peroxide values and fatty acid profile of extracted lipids were estimated according to A.O.A.C (2000).

\section{Sensory evaluation}

Caramel samples prepared by using different types of lecithins were asked for their quality attributes by ten members preference taste panel, from staff of the 
Department of Food Science, Faculty of Agriculture, Ain Shams University. The panelists were asked to score color, texture, flavor, mouth feel, overall acceptability by giving a degree ranging between 1 to 9 (no difference from $(\mathrm{R})=5$; more desirable than (R) Slight $=6$, Moderate $=7$, Much=8, Extreme=9; less desirable than (R) Slight=4, Moderate=3, Much=2, Extreme $=1$ ) where $R$ is a control sample which prepared using commercial soy lecithin. The report sheet used was described by Venkatesh et al (1984).

\section{Statistical analysis}

The obtained data was exposed to analysis of variance. Duncan multiple range at $5 \%$ level of significance was used to compare between means. Results followed by different alphabetical letters were significantly differed. The analyses were carried out using the PROC ANOVA procedure of Statistical Analysis System (SAS, 1988).

\section{RESULTS AND DISCUSSION}

EAI $\left(\mathrm{m}^{2} / \mathrm{g}\right)$ of the commercial soy lecithin, crude extracted lecithins from corn germ and sunflower oils and their modified lecithins (ethyl alcohol soluble fraction and acylated corn germ and sunflower lecithins) was examined at different $\mathrm{pH}$ values (Table, 1). The EAI for all lecithins were gradually and significantly improved with increasing the $\mathrm{pH}$ values from 2 to 10 . The ethyl alcohol soluble fraction of corn germ and sunflower lecithins had significantly the highest EAI values in comparison to other corn and sunflower lecithins ranging between 63.0 to 201.3 and 107.6 to $197.5 \mathrm{~m}^{2} / \mathrm{g}$ at $\mathrm{pH}$ values from 2 to 10 , respectively. The EAI of acylated corn germ and sunflower lecithins were in the second order having the range values of 47.5 to 162.7 and 94.3 to $152.9 \mathrm{~m}^{2} / \mathrm{g}$ at $\mathrm{pH}$ values from 2 to 10 , respectively. On the other hand, crude corn germ and sunflower lecithins had the lowest EAI values compared to their modified lecitihns. In comparison to commercial soy lecithin the data revealed that the ethanol soluble fractions had practically closed emulsifying activity, especially of corn germ to that of soy lecithin. While the other corn and sunflower lecithins shown lower emulsifying activity.

The ESI of emulsions made from tested lecithins was determined by the changes in EAI after times of 20, 40 and $60 \mathrm{~min}$. (Figure, 1). It was clearly noticed that the ESI followed the same trend of EAI, i.e., the improver the EAI, the greater in its stability. It could be noticed that the stability of both modified lecithins was more than that of commercial soy lecithin. The crude corn germ and sunflower lecithins encouraged relatively coalescence and creaming, this was possible because of the increasing of average droplet oil diameter. However emulsions made with ethanol soluble fraction and acylated lecithins markedly improved creaming stability and retarded coalescence. It was appeared that the most important factor affecting creaming stability is particle diameter. This observation was in accordance with Stok's low. In this respect, Hollo et al (1993) indicated that acylation improved EAI and ESI by acylated the amino groups in phosphatidylethanolamine. While, according to Agboola et al (1998), the mechanism by 
Table 1. Emulsification activity index $\left(\mathrm{m}^{2} / \mathrm{g}\right)$ of commercial soy lecithin, crude corn and sunflower lecithins and their modified forms at different $\mathrm{pH}$ values

\begin{tabular}{|c|c|c|c|c|c|c|}
\hline \multirow{2}{*}{\multicolumn{2}{|c|}{ Lecithin types }} & \multicolumn{5}{|c|}{$\mathrm{pH}$ values } \\
\hline & & 2 & 4 & 6 & 8 & 10 \\
\hline \multicolumn{2}{|c|}{ Commercial soy } & $27.6^{\mathrm{Ge}}$ & $145.9^{\mathrm{Ad}}$ & $179.6^{\mathrm{Ac}}$ & $182.9^{\mathrm{Ab}}$ & $205.2^{\mathrm{Aa}}$ \\
\hline \multirow{2}{*}{$\frac{\theta}{\tilde{E}}$} & Corn & $53.6^{\mathrm{Ee}}$ & $105.6^{\mathrm{Dd}}$ & $109.6^{\mathrm{Dc}}$ & $116.0^{\mathrm{Fb}}$ & $141.1^{\mathrm{Fa}}$ \\
\hline & Sunflower & $83.6^{\mathrm{Ce}}$ & $92.9^{\mathrm{Ed}}$ & $103.3^{\mathrm{Dc}}$ & $110.0^{\mathrm{Gb}}$ & $138.9^{\mathrm{Ga}}$ \\
\hline \multirow{4}{*}{ 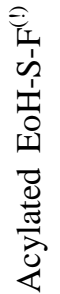 } & Corn & $63.0^{\mathrm{Dd}}$ & $119.9^{\mathrm{Cc}}$ & $167.6^{\mathrm{Bb}}$ & $177.7^{\mathrm{Bb}}$ & $201.3^{\mathrm{Ba}}$ \\
\hline & Sunflower & $107.6^{\mathrm{Ae}}$ & $121.8^{\mathrm{Bd}}$ & $163.9^{\mathrm{Bc}}$ & $169.8^{\mathrm{Cb}}$ & $197.5^{\mathrm{Ca}}$ \\
\hline & Corn & $47.5^{\mathrm{Fe}}$ & $105.9^{\mathrm{Dd}}$ & $126.7^{\mathrm{Cc}}$ & $140.6^{\mathrm{Db}}$ & $162.7^{\mathrm{Da}}$ \\
\hline & Sunflower & $94.3^{\mathrm{Bd}}$ & $93.0^{\mathrm{Ee}}$ & $124.5^{\mathrm{Cc}}$ & $133.2^{\mathrm{Eb}}$ & $152.9^{\mathrm{Ea}}$ \\
\hline
\end{tabular}

${ }^{(1)}$ EoH-S-F= ethanol soluble fraction

-Capital and small letters were used for comparison between means in the vertical and horizontal directions, respectively.

-Means with the same letter are not significantly different $(\mathrm{P}>0.05)$.

which creaming stability is preserved in system containing modified lecithin is unclear. The increasing of ESI of modified lecithin may also due to the improvement of their hydrophilic/lypophilic balance that lowered more effectively the interfacial tension of the film between oil droplets and water in the emulsion.

The improvement of EAI and ESI in emulsions prepared using ethyl alcohol soluble fraction lecithins ascribed to enriched its fractions with phosphatidylcholine (Van Nieuwenhuyzen, 1999; Wu and Wang, 2003). It could be concluded that the modified corn germ and sunflower lecithins give a good emulsification properties closed to that of commercial soy lecithin compared to their crude forms.

Textural measurement (Hardness) of caramel samples prepared by using different lecithins, was examined at zero time. The obtained data was presented in Figure (2). Insignificant difference was observed $(p>0.05)$ between the prepared samples ranging between 532 to $605 \mathrm{~N}$. The mutual approach of moisture content in different caramel samples ranging between 15.3 to $15.9 \%$ was considered the responsible about the closed hardness values with insignificant difference. 
Fig. 1. Emulsion stability index $\left(\mathrm{m}^{2} / \mathrm{g}\right.$ lecithin) of (A) commercial soy lecithin, (B) crude corn and sunflower lecithins, $(\mathbf{C})$ ethanol soluble fraction of corn and sunflower lecithins, (D) acylated corn and sunflower lecithins at different $\mathrm{pH}$ values and times. 

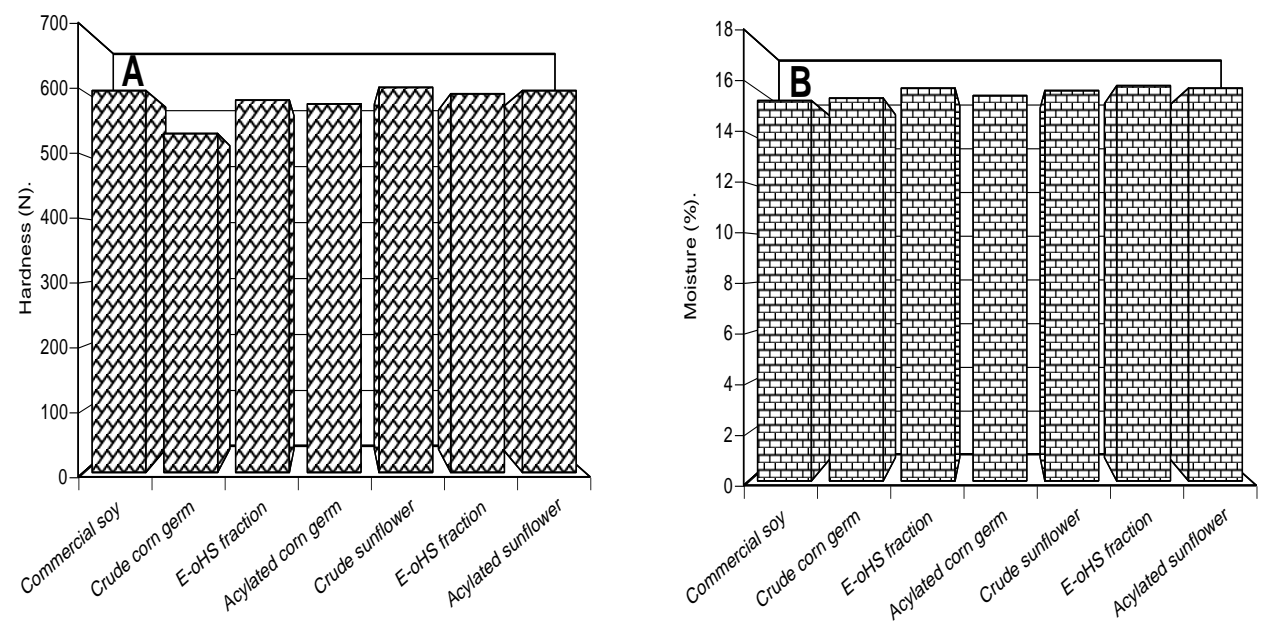

Fig. 2. Effect of different lecithin sources on hardness (A) and moisture content (B) of caramel samples

Data in Table (2) indicated that the extracted lipids from caramels prepared using tested lecithins had acid values ranging between 0.06 to 0.17 without significant difference $(\mathrm{P}>0.05)$ at zero time. The acid values were gradually increased versus storage period with significant difference. The values reached their maximal ranging "between" 0.89 to 1.20 after 6 month. These increases were probably due to lipolysis occurred by lipases in ingredients such as condensed whole milk. Such enzymes, which are often very heat-resistant, break down the triglycerides of the fat into its constituent fatty acids (Young, 1983). The free fatty acids may also produced in advanced state of double bonds oxidation of unsaturated fatty acids esters (Mounts and List, 1996).
Table (3) showed that the extracted lipids from caramel samples had peroxide values ranging between 0.16 to 0.27 $\mathrm{meq} / \mathrm{kg}$ at zero time without significant differences. These values were more than that of the fat $(0.00 \mathrm{meq} / \mathrm{kg})$ used in preparation, due to the cooking treatment. Reifsteck and Jeon (2000) reported that the thermal induced oxidation involves hydrogen radical abstraction on lipids with the addition of molecular oxygen to form the peroxide radical followed by the formation of hydrogen peroxide. On storage at room temperature, the peroxide values of extracted lipids substantially increased reaching their maximal values at the end of storage period in all samples with significant differences in comparison to values at zero time. The peroxide values of extracted lipids from caramel samples prepared by using crude 
Table 2. Acid value of extracted lipids from caramels prepared by using commercial soybean lecithin, crude corn germ and sunflower lecithins and their modified forms during storage at room temperature

\begin{tabular}{|c|c|c|c|c|c|c|c|}
\hline \multirow{2}{*}{ 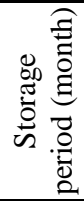 } & \multirow[b]{2}{*}{ 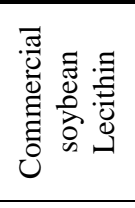 } & \multicolumn{2}{|c|}{ Crude } & \multicolumn{2}{|c|}{${ }^{(1)}$ EoH-S-F lecithin } & \multicolumn{2}{|c|}{ Acylated } \\
\hline & & 豆 & 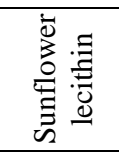 & 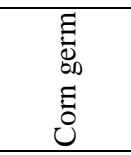 & $\begin{array}{l}\overline{0} \\
\vdots \\
0 \\
\vdots \\
\vdots \\
\dot{a} \\
\end{array}$ & 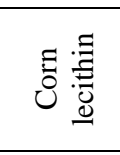 & 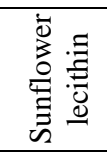 \\
\hline 0 & $0.14^{\mathrm{Da}}$ & $0.06^{\mathrm{Ca}}$ & $0.15^{\mathrm{Ca}}$ & $0.12^{\mathrm{Da}}$ & $0.13^{\mathrm{Aa}}$ & $0.13^{\mathrm{Ca}}$ & $0.17^{\mathrm{Ba}}$ \\
\hline 1 & $0.50^{\mathrm{CDa}}$ & $0.50^{\mathrm{Bca}}$ & $0.50^{\mathrm{BCa}}$ & $0.32^{\mathrm{CDa}}$ & $0.60^{\mathrm{ABa}}$ & $0.45^{\mathrm{BCa}}$ & $0.70^{\mathrm{ABa}}$ \\
\hline 2 & $0.53^{\mathrm{CDa}}$ & $0.65^{\mathrm{ABa}}$ & $0.52^{\mathrm{ABCa}}$ & $0.50^{\mathrm{BCDa}}$ & $0.65^{\mathrm{ABa}}$ & $0.65^{\mathrm{ABCa}}$ & $0.72^{\mathrm{ABa}}$ \\
\hline 3 & $0.61^{\mathrm{Ca}}$ & $0.70^{\mathrm{ABa}}$ & $0.53^{\mathrm{ABCa}}$ & $0.55^{\mathrm{BCDa}}$ & $0.70^{\mathrm{ABa}}$ & $0.69^{\mathrm{ABCa}}$ & $0.80^{\mathrm{ABa}}$ \\
\hline 4 & $0.70^{\mathrm{BCa}}$ & $0.70^{\mathrm{ABa}}$ & $0.55^{\mathrm{ABCa}}$ & $0.66^{\mathrm{BCa}}$ & $0.70^{\mathrm{ABa}}$ & $0.70^{\mathrm{ABCa}}$ & $0.80^{\mathrm{ABa}}$ \\
\hline 5 & $1.05^{\mathrm{ABa}}$ & $0.73^{\mathrm{ABa}}$ & $0.75^{\mathrm{ABa}}$ & $0.87^{\mathrm{ABa}}$ & $0.87^{\mathrm{Aa}}$ & $0.88^{\mathrm{ABa}}$ & $0.81^{\mathrm{ABa}}$ \\
\hline 6 & $1.20^{\mathrm{Aa}}$ & $1.09^{\mathrm{Aa}}$ & $1.03^{\mathrm{Aa}}$ & $1.19^{\mathrm{Aa}}$ & $0.89^{\mathrm{Aa}}$ & $1.20^{\mathrm{Aa}}$ & $0.89^{\mathrm{Aa}}$ \\
\hline
\end{tabular}

Table 3. Peroxide value of extracted lipids from caramels prepared by using commercial soybean lecithin, crude corn germ and sunflower lecithins and their modified forms during storage at room temperature

\begin{tabular}{|c|c|c|c|c|c|c|c|}
\hline \multirow[b]{2}{*}{ 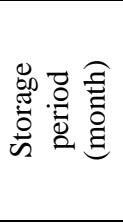 } & \multirow{2}{*}{ 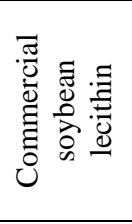 } & \multicolumn{2}{|c|}{ Crude } & \multicolumn{2}{|c|}{$\begin{array}{l}{ }^{(1)} \mathrm{EoH}-\mathrm{S}-\mathrm{F} \text { lecithin } \\
\text { of }\end{array}$} & \multicolumn{2}{|c|}{ Acylated } \\
\hline & & Ð0 & 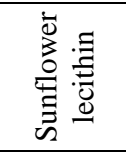 & $\begin{array}{l}E \\
\tilde{D} \\
\infty \\
\Xi \\
0\end{array}$ & 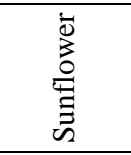 & Ẽ & 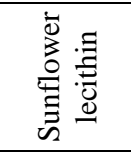 \\
\hline 0 & $0.16^{\mathrm{Ca}}$ & $0.20^{\mathrm{Ca}}$ & $0.18^{\mathrm{Ca}}$ & $0.18^{\mathrm{Ba}}$ & $0.18^{\mathrm{Ca}}$ & $0.27^{\mathrm{Da}}$ & $0.20^{\mathrm{Da}}$ \\
\hline 1 & $0.37^{\mathrm{Ca}}$ & $0.35^{\mathrm{Ca}}$ & $0.46^{\mathrm{Ca}}$ & $0.36^{\mathrm{Ba}}$ & $0.54^{\mathrm{Ca}}$ & $0.53^{\mathrm{Da}}$ & $0.44^{\mathrm{CDa}}$ \\
\hline 2 & $1.00^{\mathrm{Ca}}$ & $1.15^{\mathrm{BCa}}$ & $1.43^{\mathrm{Ca}}$ & $1.25^{\mathrm{ABa}}$ & $1.15^{\mathrm{BCa}}$ & $1.47^{\mathrm{Da}}$ & $1.58^{\mathrm{CDa}}$ \\
\hline 3 & $2.50^{\mathrm{BCa}}$ & $2.50^{\mathrm{ABCa}}$ & $5.00^{\mathrm{Ba}}$ & $2.78^{\mathrm{ABa}}$ & $2.27^{\mathrm{ABCa}}$ & $4.57^{\mathrm{Ca}}$ & $3.58^{\mathrm{BCDa}}$ \\
\hline 4 & $3.12^{\mathrm{ABCc}}$ & $3.33^{\mathrm{ABCc}}$ & $6.67^{\mathrm{ABa}}$ & $3.12^{\mathrm{ABc}}$ & $3.75^{\mathrm{ABCbc}}$ & $5.88^{\mathrm{BCa}}$ & $5.38^{\mathrm{ABCab}}$ \\
\hline 5 & $5.35^{\mathrm{ABbc}}$ & $4.17^{\mathrm{ABc}}$ & $7.50^{\mathrm{ABab}}$ & $4.28^{\mathrm{ABc}}$ & $4.69^{\mathrm{ABc}}$ & $8.12^{\mathrm{ABa}}$ & $7.47^{\mathrm{ABab}}$ \\
\hline 6 & $6.19^{\mathrm{Abc}}$ & $5.56^{\mathrm{Ac}}$ & $7.72^{\text {Aab }}$ & $5.26^{\mathrm{Ac}}$ & $5.35^{\mathrm{Ac}}$ & $9.09^{\mathrm{Aa}}$ & $8.63^{\mathrm{Aa}}$ \\
\hline
\end{tabular}

${ }^{(1)} \mathrm{EoH}-\mathrm{S}-\mathrm{F}=$ ethanol soluble fraction

-Capital and small letters were used for comparison between means in the vertical and horizontal directions, respectively.

-Means with the same letter are not significantly different $(\mathrm{P}>0.05)$.

Arab Univ. J. Agric. Sci., 13(2), 2005 
sunflower, acylated corn germ and sunflower lecithins were significantly overabundance (ranging between 7.72 to 9.09 $\mathrm{meq} / \mathrm{kg}$ ) of those prepared by using commercial soy, crude corn germ, ethanol soluble fraction of corn germ and sunflower lecithins (ranging between 5.26 to $6.19 \mathrm{meq} / \mathrm{kg}$ ) at the end of storage, owing to high content of phosphatidylcholine in these lecithins that reduced the rate of hydroperoxide formation (Nasner, 1986).

Table (4) shows the fatty acid pattern of lipids extracted from caramel samples evaluated at zero time and after 6 months. The major fatty acids at the start of storage period were palmitic acid $42.40 \%$, followed by oleic acid $36.24 \%$, linoleic acid $7.37 \%$ and stearic acid $6.64 \%$. However, minor amounts, about $1 \%$ or less were detected for caproic, caprylic, capric, lauric, arachidic, behenic, myristoleic, palmitoleic, lenolenic and gadoleic. The total saturated fatty acids increased gradually from $54.58 \%$ during storage at room temperature reached to their maximal values ranging between 55.31 and 58.10 after 6 months.

These increases were mainly due to the increase of palmitic, stearic acids and the reduction of unsaturated fatty acids, mainly mono-unsaturated ones. The decreases in total unsaturated fatty acids could be attributed to partially oxidation of the double bonds in oleic and lenoleic acids to form peroxides, hydroperoxides, carbonyl compounds and further oxidative cleavage products. These oxidative reactions were slower for caramel samples prepared by using commercial soy lecithin, crude corn germ and ethanol soluble fraction lecithins due to their higher contents of phosphatidylcholine than other lecithins (Weber, 1981; Neidleman, 1993; Wu and Wang, 2003) and the best anti-oxidative effects obtained with ethanol soluble fraction, this fact agreed with the results reported by Nasner (1986).

The mean values of sensory evaluation scores of caramel samples are shown in Table (5). It could be noticed that the color and flavor of all samples at all storage period were closed without any significant differences in their mean score values.

Texture is an important quality attribute of caramel, which related to its physical properties. The fresh caramel samples prepared by using corn germ and sunflower lecithins received higher values than that of control sample prepared by using commercial soy lecithin without significant difference. The score values were declined during storage period with significant difference $(\mathrm{P}<0.05)$ in caramel samples prepared using crude sunflower and its ethanol soluble fraction lecithins and acylated corn germ lecithin. The mouthfeel of caramel samples followed the same trend of texture. The mean values among samples prepared using modified lecithins were higher than those of commercial soy lecithin and crude lecithins. While, all samples crossed the end storage period without significant difference, except caramel prepared using sunflower ethanol soluble fraction. The means of panelist score values on overall acceptability of caramel samples reflected all the previously judged quality attributes; it followed approximately a similar pattern.

In summary, the data showed that the modified corn germ and sunflower lecithins were good emulsifiers owing to their higher emulsifying activity. The prepared caramel samples using the modified lecithin forms showed a suitable 
Table 4. Fatty acid composition of extracted lipids from caramel manufactured using commercial soybean lecithin, crude corn germ and sunflower lecithins and their modified forms at zero time and after storage period for 6 month at room temperature

\begin{tabular}{|c|c|c|c|c|c|c|c|c|}
\hline \multirow[b]{3}{*}{ 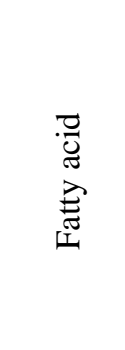 } & \multirow{3}{*}{$\begin{array}{l}\stackrel{\Xi}{\Xi} \\
. \\
\stackrel{0}{0} \\
N\end{array}$} & \multicolumn{7}{|c|}{ After 6 month } \\
\hline & & \multirow[b]{2}{*}{ 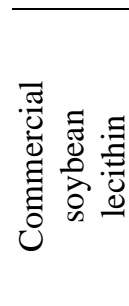 } & \multicolumn{2}{|c|}{ Crude } & \multicolumn{2}{|c|}{$\begin{array}{l}{ }^{(1)} \mathrm{EoH}-\mathrm{S}-\mathrm{F} \text { lecithin } \\
\text { of }\end{array}$} & \multicolumn{2}{|c|}{ Acylated } \\
\hline & & & 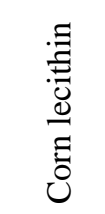 & 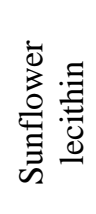 & 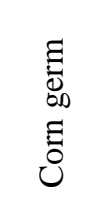 & $\begin{array}{l}\overline{0} \\
\vdots \\
\vdots \\
\vdots \\
\vdots \\
\vdots\end{array}$ & 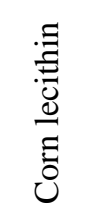 & 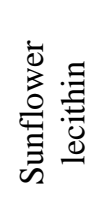 \\
\hline$C: 6$ & 0.56 & 0.43 & 0.46 & 0.62 & 0.50 & 0.42 & 0.59 & 0.47 \\
\hline $\mathrm{C}: 8$ & 0.30 & 0.26 & 0.29 & 0.35 & 0.30 & 0.24 & 0.31 & 0.29 \\
\hline $\mathrm{C}: 10$ & 0.55 & 0.52 & 0.60 & 0.63 & 0.59 & 0.49 & 0.61 & 0.54 \\
\hline $\mathrm{C}: 12$ & 0.87 & 0.93 & 0.98 & 1.00 & 1.00 & 0.86 & 1.03 & 0.92 \\
\hline $\mathrm{C}: 14$ & 2.92 & 2.98 & 3.15 & 3.21 & 3.14 & 2.81 & 3.32 & 2.96 \\
\hline$C: 16$ & $\begin{array}{c}42.4 \\
0\end{array}$ & 42.16 & 42.01 & 43.04 & 43.30 & 41.82 & 44.10 & 43.26 \\
\hline $\mathrm{C}: 18$ & 6.64 & 7.70 & 8.10 & 9.69 & 7.54 & 10.26 & 8.00 & 9.84 \\
\hline$C: 20$ & 0.23 & 0.24 & 0.01 & 0.00 & 0.05 & 0.18 & 0.01 & 0.00 \\
\hline $\mathrm{C}: 22$ & 0.10 & 0.11 & 0.12 & 0.12 & 0.11 & 0.10 & 0.14 & 0.10 \\
\hline $\mathbf{S F A}^{(2)}$ & 54.58 & 55.31 & 55.70 & 58.65 & 56.52 & 57.18 & 58.10 & 58.39 \\
\hline C14:1 & 0.59 & 0.49 & 0.54 & 0.52 & 0.53 & 0.45 & 0.55 & 0.46 \\
\hline C16:1 & 0.75 & 0.48 & 0.61 & 0.49 & 0.33 & 0.26 & 0.62 & 0.43 \\
\hline C18:1 & $\begin{array}{c}36.2 \\
4\end{array}$ & 35.21 & 34.92 & 32.46 & 34.85 & 34.76 & 33.24 & 32.63 \\
\hline C18:2 & 7.37 & 8.01 & 7.73 & 7.36 & 7.28 & 6.89 & 6.99 & 7.60 \\
\hline C18:3 & 0.32 & 0.34 & 0.33 & 0.34 & 0.33 & 0.32 & 0.33 & 0.33 \\
\hline C20:1 & 0.14 & 0.16 & 0.16 & 0.17 & 0.16 & 0.14 & 0.17 & 0.14 \\
\hline USFA $^{(3)}$ & 45.42 & 44.68 & 44.30 & 41.35 & 43.48 & 42.82 & 41.90 & 41.61 \\
\hline
\end{tabular}

${ }^{(1)} \mathrm{EoH}-\mathrm{S}-\mathrm{F}=$ ethanol soluble fraction

(2) SFA = Saturated fatty acids

${ }^{(3)}$ USFA = Unsaturated fatty acids 
Table 5. Mean values of sensory evaluation of caramel prepared by using commercial soybean lecithin and modified corn germ and sunflower lecithins

\begin{tabular}{|c|c|c|c|c|c|c|c|}
\hline \multirow{2}{*}{$\begin{array}{l}\text { Storage } \\
\text { period } \\
\text { (month) }\end{array}$} & \multirow{2}{*}{$\begin{array}{c}\text { Commercial } \\
\text { soybean } \\
\text { lecithin }\end{array}$} & \multicolumn{2}{|c|}{ Crude } & \multicolumn{2}{|c|}{${ }^{(1)}$ EoH-S-F lecithin of } & \multicolumn{2}{|c|}{ Acylated } \\
\hline & & $\begin{array}{l}\text { Corn } \\
\text { lecithin }\end{array}$ & $\begin{array}{c}\text { Sunflower } \\
\text { lecithin }\end{array}$ & $\begin{array}{l}\text { Corn } \\
\text { germ }\end{array}$ & Sunflower & $\begin{array}{l}\text { Corn } \\
\text { lecithin }\end{array}$ & $\begin{array}{c}\text { Sunflower } \\
\text { lecithin }\end{array}$ \\
\hline \multicolumn{8}{|c|}{ Color } \\
\hline 0 & $5.0^{\mathrm{Aa}}$ & $5.3^{\mathrm{Aa}}$ & $5.0^{\mathrm{Aa}}$ & $5.0^{\mathrm{Aa}}$ & $5.0^{\mathrm{Aa}}$ & $6.0^{\mathrm{Aa}}$ & $6.3^{\mathrm{Aa}}$ \\
\hline 1 & $5.0^{\mathrm{Aa}}$ & $5.0^{\mathrm{ABa}}$ & $5.0^{\mathrm{Aa}}$ & $5.0^{\mathrm{Aa}}$ & $5.0^{\mathrm{Aa}}$ & $5.3^{\mathrm{Aa}}$ & $5.6^{\mathrm{Aa}}$ \\
\hline 2 & $5.0^{\mathrm{Aa}}$ & $5.0^{\mathrm{ABa}}$ & $5.0^{\mathrm{Aa}}$ & $5.0^{\mathrm{Aa}}$ & $5.0^{\mathrm{Aa}}$ & $5.3^{\mathrm{Aa}}$ & $5.3^{\mathrm{Aa}}$ \\
\hline 3 & $5.0^{\mathrm{Aa}}$ & $5.0^{\mathrm{ABa}}$ & $5.0^{\mathrm{Aa}}$ & $5.0^{\mathrm{Aa}}$ & $5.0^{\mathrm{Aa}}$ & $5.3^{\mathrm{Aa}}$ & $5.3^{\mathrm{Aa}}$ \\
\hline 4 & $5.0^{\mathrm{Aa}}$ & $5.0^{\mathrm{ABa}}$ & $5.0^{\mathrm{Aa}}$ & $5.0^{\mathrm{Aa}}$ & $5.0^{\mathrm{Aa}}$ & $5.0^{\mathrm{Aa}}$ & $5.0^{\mathrm{Aa}}$ \\
\hline 5 & $5.0^{\mathrm{Aa}}$ & $5.0^{\mathrm{ABa}}$ & $5.0^{\mathrm{Aa}}$ & $5.0^{\mathrm{Aa}}$ & $5.0^{\mathrm{Aa}}$ & $5.0^{\mathrm{Aa}}$ & $5.0^{\mathrm{Aa}}$ \\
\hline 6 & $5.0^{\mathrm{Aa}}$ & $4.6^{\mathrm{Ba}}$ & $5.0^{\mathrm{Aa}}$ & $5.0^{\mathrm{Aa}}$ & $4.6^{\mathrm{Aa}}$ & $5.0^{\mathrm{Aa}}$ & $5.0^{\mathrm{Aa}}$ \\
\hline \multicolumn{8}{|c|}{ Flavor } \\
\hline 0 & $5.0^{\mathrm{Aa}}$ & $5.3^{\mathrm{Aa}}$ & $5.3^{\mathrm{Aa}}$ & $5.3^{\mathrm{Aa}}$ & $5.3^{\mathrm{Aa}}$ & $5.3^{\mathrm{Aa}}$ & $5.6^{\mathrm{Aa}}$ \\
\hline 1 & $5.0^{\mathrm{Aa}}$ & $5.3^{\mathrm{Aa}}$ & $5.3^{\mathrm{Aa}}$ & $5.3^{\mathrm{Aa}}$ & $5.3^{\mathrm{Aa}}$ & $5.3^{\mathrm{Aa}}$ & $5.3^{\mathrm{Aa}}$ \\
\hline 2 & $5.0^{\mathrm{Aa}}$ & $5.3^{\mathrm{Aa}}$ & $5.3^{\mathrm{Aa}}$ & $5.3^{\mathrm{Aa}}$ & $5.3^{\mathrm{Aa}}$ & $5.3^{\mathrm{Aa}}$ & $5.3^{\mathrm{Aa}}$ \\
\hline 3 & $5.0^{\mathrm{Aa}}$ & $5.3^{\mathrm{Aa}}$ & $5.3^{\mathrm{Aa}}$ & $5.3^{\mathrm{Aa}}$ & $5.3^{\mathrm{Aa}}$ & $5.3^{\mathrm{Aa}}$ & $5.3^{\mathrm{Aa}}$ \\
\hline 4 & $5.0^{\mathrm{Aa}}$ & $5.3^{\mathrm{Aa}}$ & $5.3^{\mathrm{Aa}}$ & $5.3^{\mathrm{Aa}}$ & $5.3^{\mathrm{Aa}}$ & $5.3^{\mathrm{Aa}}$ & $5.3^{\mathrm{Aa}}$ \\
\hline 5 & $5.0^{\mathrm{Aa}}$ & $5.3^{\mathrm{Aa}}$ & $5.0^{\mathrm{Aa}}$ & $5.0^{\mathrm{Aa}}$ & $5.0^{\mathrm{Aa}}$ & $5.0^{\mathrm{Aa}}$ & $5.3^{\mathrm{Aa}}$ \\
\hline 6 & $5.0^{\mathrm{Aa}}$ & $5.0^{\mathrm{Aa}}$ & $4.6^{\mathrm{Aa}}$ & $5.0^{\mathrm{Aa}}$ & $4.6^{\mathrm{Aa}}$ & $5.0^{\mathrm{Aa}}$ & $5.0^{\mathrm{Aa}}$ \\
\hline \multicolumn{8}{|c|}{ Texture } \\
\hline 0 & $5.0^{\mathrm{Ab}}$ & $5.3^{\mathrm{Ab}}$ & $5.6^{\mathrm{Aab}}$ & $6.0^{\text {Aab }}$ & $6.0^{\mathrm{Aab}}$ & $7.0^{\mathrm{Aa}}$ & $7.0^{\mathrm{Aa}}$ \\
\hline 1 & $5.0^{\mathrm{Aa}}$ & $5.3^{\mathrm{Aa}}$ & $5.6^{\mathrm{Aa}}$ & $6.0^{\mathrm{Aa}}$ & $6.0^{\mathrm{Aa}}$ & $6.6^{\mathrm{ABa}}$ & $6.6^{\mathrm{Aa}}$ \\
\hline 2 & $5.0^{\mathrm{Aa}}$ & $5.0^{\mathrm{Aa}}$ & $5.0^{\mathrm{Ba}}$ & $5.0^{\mathrm{Aa}}$ & $6.0^{\mathrm{Aa}}$ & $6.3^{\mathrm{ABa}}$ & $6.3^{\mathrm{Aa}}$ \\
\hline 3 & $5.0^{\mathrm{Aa}}$ & $5.0^{\mathrm{Aa}}$ & $5.0^{\mathrm{Ba}}$ & $5.0^{\mathrm{Aa}}$ & $5.6^{\mathrm{ABa}}$ & $6.0^{\mathrm{ABa}}$ & $6.0^{\mathrm{Aa}}$ \\
\hline 4 & $5.0^{\mathrm{Ab}}$ & $5.0^{\mathrm{Ab}}$ & $5.0^{\mathrm{Bb}}$ & $5.0^{\mathrm{Ab}}$ & $5.0^{\mathrm{ABb}}$ & $5.3^{\mathrm{ABab}}$ & $5.6^{\mathrm{Aa}}$ \\
\hline 5 & $5.0^{\mathrm{Aab}}$ & $4.6^{\mathrm{Aab}}$ & $5.0^{\mathrm{Bab}}$ & $5.0^{\mathrm{Aab}}$ & $4.3^{\mathrm{Bb}}$ & $5.0^{\mathrm{Bab}}$ & $5.3^{\mathrm{Aa}}$ \\
\hline 6 & $5.0^{\mathrm{Aa}}$ & $4.6^{\mathrm{Aa}}$ & $5.0^{\mathrm{Ba}}$ & $5.0^{\mathrm{Aa}}$ & $4.3^{\mathrm{Ba}}$ & $5.0^{\mathrm{Ba}}$ & $5.0^{\mathrm{Aa}}$ \\
\hline \multicolumn{8}{|c|}{ Mouthfeel } \\
\hline 0 & $5.0^{\mathrm{Aa}}$ & $5.3^{\mathrm{Aa}}$ & $5.3^{\mathrm{Aa}}$ & $5.6^{\mathrm{Aa}}$ & $5.6^{\mathrm{Aa}}$ & $6.3^{\mathrm{Aa}}$ & $6.3^{\mathrm{Aa}}$ \\
\hline 1 & $5.0^{\mathrm{Aa}}$ & $5.3^{\mathrm{Aa}}$ & $5.3^{\mathrm{Aa}}$ & $5.6^{\mathrm{Aa}}$ & $5.6^{\mathrm{Aa}}$ & $6.0^{\mathrm{Aa}}$ & $6.0^{\mathrm{Aa}}$ \\
\hline 2 & $5.0^{\mathrm{Aa}}$ & $5.0^{\mathrm{Aa}}$ & $5.0^{\mathrm{Aa}}$ & $5.0^{\mathrm{Aa}}$ & $5.0^{\mathrm{ABa}}$ & $5.6^{\mathrm{Aa}}$ & $5.6^{\mathrm{Aa}}$ \\
\hline 3 & $5.0^{\mathrm{Ab}}$ & $5.3^{\mathrm{Aab}}$ & $5.3^{\mathrm{Aab}}$ & $5.6^{\mathrm{Aab}}$ & $5.6^{\text {Aab }}$ & $5.6^{\text {Aab }}$ & $6.0^{\mathrm{Aa}}$ \\
\hline 4 & $5.0^{\mathrm{Aa}}$ & $5.0^{\mathrm{Aa}}$ & $5.3^{\mathrm{Aa}}$ & $5.3^{\mathrm{Aa}}$ & $5.3^{\mathrm{Aa}}$ & $5.6^{\mathrm{Aa}}$ & $5.6^{\mathrm{Aa}}$ \\
\hline 5 & $5.0^{\mathrm{Aa}}$ & $5.0^{\mathrm{Aa}}$ & $5.0^{\mathrm{Aa}}$ & $5.0^{\mathrm{Aa}}$ & $5.0^{\mathrm{ABa}}$ & $5.0^{\mathrm{Aa}}$ & $5.3^{\mathrm{Aa}}$ \\
\hline 6 & $5.0^{\mathrm{Ab}}$ & $5.0^{\mathrm{Ab}}$ & $5.0^{\mathrm{Ab}}$ & $5.0^{\mathrm{Ab}}$ & $4.3^{\mathrm{Bc}}$ & $5.0^{\mathrm{Ab}}$ & $5.6^{\mathrm{Aa}}$ \\
\hline \multicolumn{8}{|c|}{ Overall acceptability } \\
\hline 0 & $5.0^{\mathrm{Ac}}$ & $5.0^{\mathrm{Ac}}$ & $6.0^{\mathrm{Aa}}$ & $5.6^{\mathrm{Aab}}$ & $5.3^{\mathrm{Abc}}$ & $6.0^{\mathrm{Aa}}$ & $6.0^{\mathrm{Aa}}$ \\
\hline 1 & $5.0^{\mathrm{Aa}}$ & $5.0^{\mathrm{Aa}}$ & $5.6^{\mathrm{ABa}}$ & $5.6^{\mathrm{Aa}}$ & $5.3^{\mathrm{Aa}}$ & $5.6^{\mathrm{ABa}}$ & $5.6^{\mathrm{ABa}}$ \\
\hline 2 & $5.0^{\mathrm{Aa}}$ & $5.0^{\mathrm{Aa}}$ & $5.6^{\mathrm{ABa}}$ & $5.6^{\mathrm{Aa}}$ & $5.3^{\mathrm{Aa}}$ & $5.6^{\mathrm{ABa}}$ & $5.6^{\mathrm{ABa}}$ \\
\hline 3 & $5.0^{\mathrm{Aa}}$ & $5.0^{\mathrm{Aa}}$ & $5.3^{\mathrm{ABa}}$ & $5.3^{\mathrm{Aa}}$ & $5.3^{\mathrm{Aa}}$ & $5.6^{\mathrm{ABa}}$ & $5.6^{\mathrm{ABa}}$ \\
\hline 4 & $5.0^{\mathrm{Aa}}$ & $5.0^{\mathrm{Aa}}$ & $5.3^{\mathrm{ABa}}$ & $5.3^{\mathrm{Aa}}$ & $5.3^{\mathrm{Aa}}$ & $5.6^{\mathrm{ABa}}$ & $5.6^{\mathrm{ABa}}$ \\
\hline 5 & $5.0^{\mathrm{Aa}}$ & $5.0^{\mathrm{Aa}}$ & $5.0^{\mathrm{Ba}}$ & $5.0^{\mathrm{Ba}}$ & $5.0^{\mathrm{Aa}}$ & $5.6^{\mathrm{ABa}}$ & $5.6^{\mathrm{ABa}}$ \\
\hline 6 & $5.0^{\mathrm{Aa}}$ & $5.0^{\mathrm{Aa}}$ & $5.0^{\mathrm{Ba}}$ & $5.0^{\mathrm{Ba}}$ & $4.6^{\mathrm{Aa}}$ & $5.0^{\mathrm{ABa}}$ & $5.0^{\mathrm{Ba}}$ \\
\hline
\end{tabular}

${ }^{(1)} \mathrm{EoH}-\mathrm{S}-\mathrm{F}=$ ethanol soluble fraction

-Capital and small letters were used for comparison between means in the vertical and horizontal directions, respectively.

-Means with the same letter are not significantly different, $(\mathrm{P}>0.05)$ 
hardness values, high oxidative stability and sensory attributes. It could be concluded the possible utilization of natural corn germ and sunflower lecithins and their modified forms in manufacturing of confectionary products especially caramel. However, these lecithins can be competing the imported commercial soy lecithin in all emulsified food products.

\section{REFERENCES}

A.O.A.C. (2000). Official Methods of Analysis, $17^{\text {th }}$ Ed. Association of Official Analytical Chemists. Gaithersburg, MD, USA.

Agboola, S.O.; S. Harjinde; P.A. Munro; D.G. Dalgleish and A.M. Singh (1998). Stability of emulsions formed using whey protein hydrolysate: effects of lecithin addition and retorting. J. Agric. Food Chem., 46: 1814-819.

Heim, M. (2003). Caramel-Raw Materials and Formulations. Manufacturing Confectioner. 83: 55-61.

Hollo, J.; J. Peredi; A. Ruzics; M. Jeranek and A. Erdelyi (1993). Sunflower lecithin and possiblities for utilization. $\boldsymbol{J}$. Am. Oil Chem. Soc., 70: 997-1001.

Krog, N. J. (1997). Food emulsifiers and their chemical and physical properties, In: Food Emulsions, pp. 141-188. Friberg, S.E. and K. Larsson (eds.), Marcel Dekker, New York.

Mounts, T.L. and G.R. List (1996). Storage, stability, and transportation of fats and oils. In: Bailey's Industrial Oil and Fat Products, $5^{\text {th }}$ (ed.), p. 411. Hui, Y.H. John Wiley \& Sons, Inc. 605 Third Avenue, New York, NY 10158-0012, USA.
Nasner, A. (1986). Antioxidizing properties of lecithin. In: Lipid Oxidation. Biological and Food Chemical Aspects, by Marcuse, R. Conference Goeteborg, Sweden. 22-23 April 1985. Goeteborg, Sweden; Scandinavian Forum for Lipid research and Technology. (c.f. FSTA 8901-N0009).

Neidleman, S.L. (1993). Occurrence and response to environmental stresses in nonmammalian organisms. In: Phospholipids Handbook; pp. 30-31. Cevc, G. (ed.) Marcel Dekker, INC. 270 Madison Avenue, New York, New York 10016.

Pearce, K.N. and J.E. Kinsella (1978). Emulsifying properties of proteins: Evaluation of a turbidimetric technique. $J$. Agric. Food Chem., 26: 716-723.

Pearson, D. (1976). The Chemical Analysis of Foods. pp. 37-438. Longman Inc., 19 West $44^{\text {th }}$ Street, New York.

Reifsteck, B.M. and I.J. Jeon (2000). Retention of volatile flavors in confections by extrusion processing. Food Rev. Int. 16: 435-452.

SAS Program (1988). SAS/STAT User's Guide, Release 6.03 Edition SAS Inst. Inc. Cary, NC., USA.

Smith, J. (1998). The essential ingredient. Confectionery Production, 64: 2425.

Sosada, M.; Z. Dutkiewicz and B. Pasker (1994). Rapeseed wet gum as a direct source of high quality lecithin. Fat Sci. Technol., 96: 28-30.

Stansell, D. (1995). Caramel, toffee and fudge. In: Sugar Confectionery Manufacture $2^{\text {nd }}$ (ed.), p. 175. Jackson, E.B. (eds.), Blacie Academic \& Professional, Chapman \& Hall, 2-6 Boundary Row, London SEI 8HN, UK.

Temelli, F. and N.T. Dunford (1995). Modification of crude canola lecithin for food use. J. Food Sci., 60: 160-163. 
Tonucci, L.H. and J.H. Von Elbe (1988). Effect of cooking temperature and variations in sweetened condensed whole milk on textural properties of caramel confections. J. Food Processing \& Prservation, 12: 125-138.

Van Nieuwenhuyzen, W. (1999). Lecithins, Functional emulsifiers in food and non-food applications. Agro. Food Industry Hi. Tech., 10: 11-14.

Venkatesh, K.V.L.; S. Dhanaraj; B. Mahadevaiah; S.M. Ananthakrishna (1984). Studies on packaging and storage of sohan halwa. The Ind. J. Nutr. Dietet, 20: 241-248.

Weber, E.J. (1981). Compositions of commercial corn and soybean lecithins. $\boldsymbol{J}$. Am. Oil Chem. Soc., 72: 898-901.

Wu, Y. and T. Wang (2003). Soybean lecithin fraction and functionality. J. Am. Oil Chem. Soc. 80: 319-326.

Young, C.C. (1983). Rancidity in confectionery products. In: Rancidity in Food; p. 180. Allen, J.C. and R.J. Hamilton (eds.), Applied Science Publishers LTD. Ripple Road, Barking, Essex, England.

بحلة اتحاد الجامعات العربية للدراسات والبحوث الزراعية ، جامعة عين شمس ، القاهرة ، 13(2) ، 351 - 365 ، 2005 إستخدام جنين الأرة ويذور عباد الشمس كمصادر جديدة لليسيثين وصورة المعدلة في تصنيع الكراميل

$$
\begin{aligned}
& \text { ياسر فكرى محمد كثلك1 - سلوى محمود ابو الفتوح'1 } \\
& \text { 1- قسم علوم الأغذية- كلية الزراعة- جامعة عين شمس- شبرا الخيمة- القاهرة- مصر }
\end{aligned}
$$

$$
\begin{aligned}
& \text { الايثانول والمعاملة بحامض الخليك اللامـائى } \\
& \text { في تعديل كل من ليسيثين جنين الذرة و عبـاد }
\end{aligned}
$$

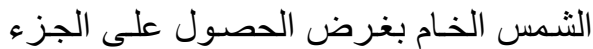

$$
\begin{aligned}
& \text { الذائب في الكحـول و الـذي يتصـف بإرتفـاع } \\
& \text { محتو اة من الفوسفاتيديل كولين وكذللك إدخال } \\
& \text { مجاميع الميثيل على جزئ الليسيثين في كلا } \\
& \text { المعاملتين على الترتيب. }
\end{aligned}
$$$$
\text { تم تقييم كل من معامل النشاط الاستحلابى لـي }
$$

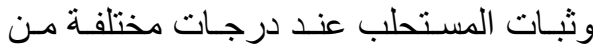

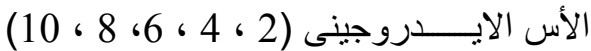

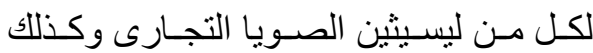

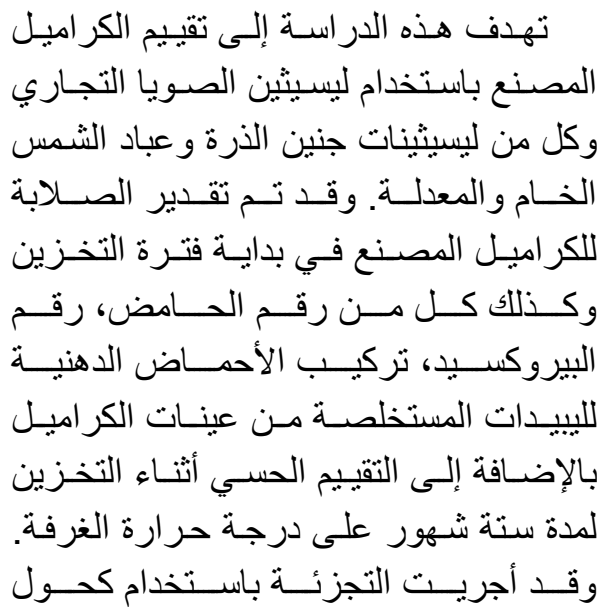
المصنح بان وكل من ليسينينات جنين الذره و عباد السمس

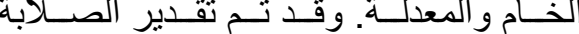
للكر اميـل المصـنع فـي بدايـة فــرة التخـرين

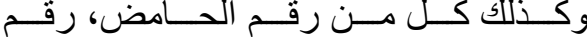
لليبيـدات المستحلصسة مسن عينـات الكر اميـل بالإضـافة إلىى التقيهم الحسـي أثنـاء التخـزين

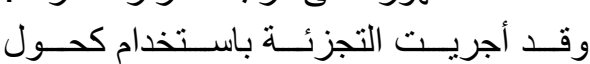


و الذى تم معاملتهما بحامض الخليك التلجي

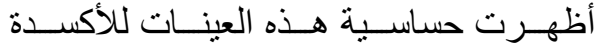

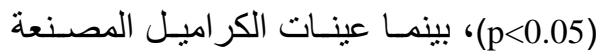

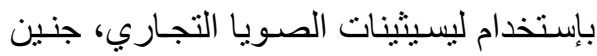

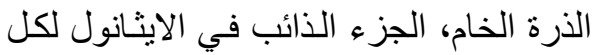

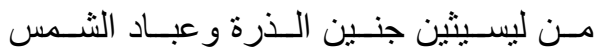
أظهرت ثبات عالي مضاد للأكسدة.

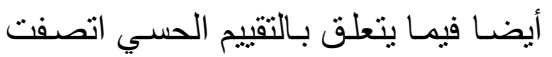

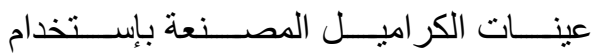
الليسيثينات المعدلة بعدم وجود فروق معنويـة الكية

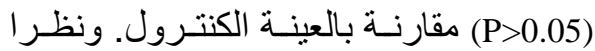

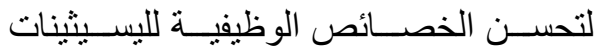

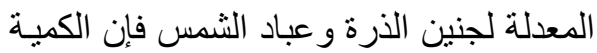

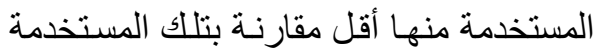

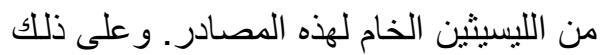

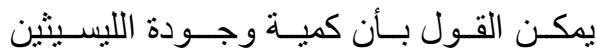

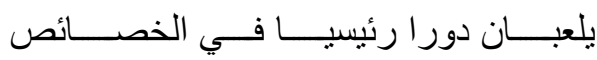

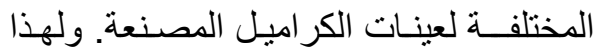

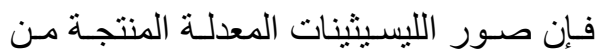

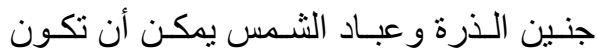

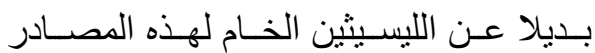

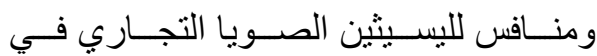

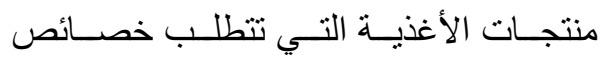
إستحلابية جيدة.

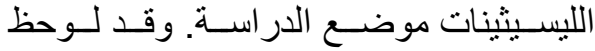

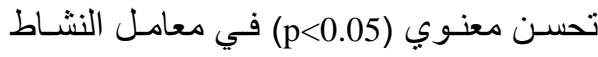

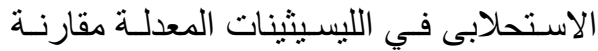
بالليسـيثين الخـام بمعـدل زئهـادة قدرة 52.6 و58.6 \% لكل من الجزء الذائب في الكحول

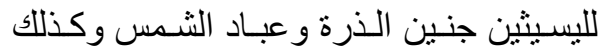

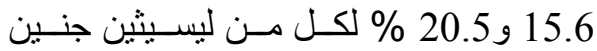

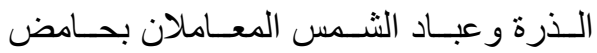

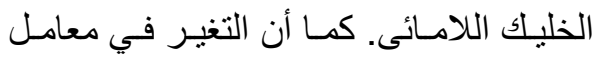

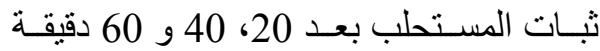

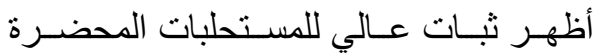

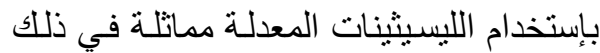
لثبات المستحلب المحضر بإستخدام ليسيثين الصويا التجاري.

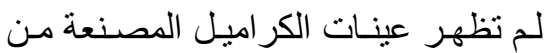

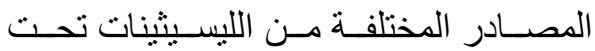

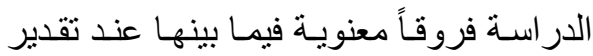

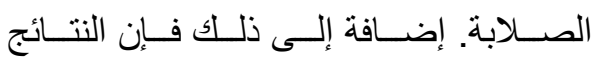

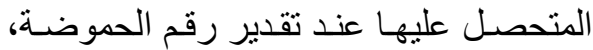
رقم البيروكسبد وتركيب الأحمـاض الدهنيـة في الليبيدات المستخلصة من عينات الكر اميل

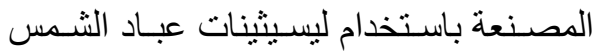

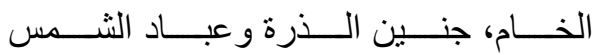

